\title{
Accounting Principles Compliance - the True and Fair View Recipe. A Theoretical Perspective on the Contribution of Accounting Principles to the Financial Reporting Objective Achievement
}

\author{
Claudia Cătălina CIOCAN, Ec. PhD \\ "Alexandru Ioan Cuza" University of Iaşi, Romania
}

\begin{abstract}
This paper explores the significance of the true and fair view, as the main objective of financial reporting to which accounting principles are subordinated, and the relationship between it and all accounting principles, focusing on identifying their contribution to achieving the true and fair view and, simultaneously, the potential conflicts. To address this issue, several interpretations of the true and fair view objective were analyzed together with the way the requirements of each accounting principle contribute to the achievement of this objective. The paper highlights that the true and fair view recipe involves contributions such as aggregating values from different reporting periods, separately reflecting assets and liabilities to prevent hiding part of a company's wealth or masking the risks that the company is facing, accurate, neutral and free from error/omission representation of transactions, establishing an acceptable materiality level that does not allow information to be over contracted or overcrowded with insignificant details, reflecting the economic substance of the transaction instead of the legal one, a realistic and balanced estimation of the risks and value losses, the presentation of past rights and obligations without being limited by their effective settlement date.
\end{abstract}

Key terms: true and fair view, accounting principles, the quality of information, information objectivity, prudence, timeliness

JEL Classification: M41

To cite this article: Claudia Cătălina Ciocan, Accounting Principles Compliance - the True and Fair View Recipe. A Theoretical Perspective on the Contribution of Accounting Principles to the Financial Reporting Objective Achievement, CECCAR Business Review, N²11/2021, pp. 49-61, DOI: http://dx.doi.org/10.37945/cbr.2021.11.07

\section{Introduction}

Accounting is based on a series of guidelines known in the accounting theory and practice as accounting principles, which apply to all accounting records and provide a common basis for a better understanding and comparability of financial statements. These statements provide information about the performance and financial position of an entity and may be of value to a wide and diverse range of users and are of real interest, especially given that accounting has been and is marked by the existence of two large accounting systems: the Anglo-Saxon accounting system and the Continental European (or Continental) accounting system.

Thus, on the one hand, for companies in the Anglo-Saxon environments, which are financed through capital markets and for which there must be a high degree of transparency, there is an obligation to respect the prevalence of economic reality over legal appearance and the true and fair view, a predominant concept in Anglo-Saxon financial reporting (Colasse, 2009; Ciocan and Georgescu, 2018). Alternatively, Nobes and Parker (2016, p. 36) states that in most continental European countries and in Japan, the small number of shareholders meant that 
financial reporting was largely aimed at protecting creditors and informing the state as a main tax collector, thus leading to a much more important role of the conservatism principle.

Without detailing all other differences in financial reporting that were recorded due to belonging to one of the two major accounting systems (differences concerning the users of accounting information, the legal sources, the role of the accounting profession in the development of accounting regulations, the connection between accounting and taxation, financing tradition) in this paper we consider the particularization of the fundamental accounting principles in Romanian accounting, marked by the Continental European accounting culture and the convergence process between the national accounting regulations and the International Financial Reporting Standards issued by the IASB.

The paper introduces interpretations of the true and fair view and research directions on this topic from the accounting literature, seeking to explore its significance, as the financial reporting objective and the relationship between it and all accounting principles, with emphasis on identifying the contribution of each principle in obtaining the true and fair view and, simultaneously, the potential conflicts between the accounting principles and the financial reporting objective. The methodological approach is inductive and aims exclusively at qualitative methods, the main ones being the documentation (analysis of the accounting literature) and the comparative analysis by resorting to a critical examination.

\section{The true and fair view concept: interpretations and research directions}

The true and fair view concept has been often considered an element of differentiation between the Anglo-Saxon and Continental European accounting system. For countries who favour the Anglo-Saxon system, this is the "ultimate principle" according to which accountants must be guided in the preparation of financial statements. Once accepted in the accounting regulations of the continental countries, true and fair view has been assimilated into the financial reporting objective, a meaning that remains valid today according to the presentation proposed by the IASB. In the latest context its achievement is considered to be reached mainly by respecting generally accepted accounting principles and, simultaneously, by complying with the requirements regarding the quality of financial accounting information.

The main difference between principle and objective can be summarised as follows: the principle is assimilated to a rule of conduct that guides the activity, and the objective is the purpose of an activity or process. In this paper, the true and fair view is centred around the financial reporting process and represents its purpose, namely, to provide users interested in useful information about the financial position, performance and cash flows of an entity.

Collet (1990) stated that the true and fair view is recognised as a statement of intent: the intention of information producers to prepare annual financial statements that accurately present the company's results, and to achieve it accounting principles apply, an opinion found in Stolowy et al. (2013, p. 122), Horomnea et al. (2016, p. 118) and lonașcu (2003, p. 68) which also argue that the concept-reality-representation relationship is the basis for the validation of accounting principles, which are constructed in an inductive manner that indicates "how" accounting should be.

Rivero (cited in Gómez Ciria, 1997) considers that four interpretations can be attributed to the true and fair view:

(1) Synonymous with precision, objectivity and truth - if the accounting information reflects everything that is important in a clear and error-free manner, the true and fair view requirement is accomplished;

(2) Compliance with accounting principles - it can be stated that this is in fact the most used interpretation;

(3) The prevalence of substance over form - which supports the prevalence of the economic form of a transaction to the detriment of its legal form in order to meet the true and fair view requirement;

(4) Synonymous with the usefulness of the information - more precisely, by its application it is intended that the information provided to be useful to the interested users who are to make decisions according to them.

The presented interpretations are not mutually exclusive. In reality, the true and fair view concept can represent all that is described above, according to Gómez Ciria (1997). The author states that this concept brings 
together, in a compact expression, all the requirements that should be met by financial statements (objectivity, decision usefulness, compliance with accounting principles and lack of errors).

Cañibano (2007) argues that the interpretation of the true and fair view in the European Union Member States has oscillated between two orientations, a legal one and an economic one. According to the first, financial statements represent the true and fair view when they have been drawn up in accordance with the legal regulations in force (such as in the case of France, Spain and Germany), while, according to the economic orientation, the financial statements must report the economic reality of the company, although it implies to no longer comply with certain legal provisions (the case of Great Britain, Netherlands and Denmark).

Starting with 1990, the year that marks Romania's transition from a centralized accounting system to the continental origin-accounting system, a first use of the true and fair view concept can be identified within the Accounting Law No. 82/1991 and its Implementing Regulation, approved by the Government Decision No. 704/1993. According to the provisions of these regulations, the objective of financial statements is to provide a true and fair view of the financial position, performance and other information relating to the business of an entity. At this stage, the true and fair view is interpreted as compliance with the valuation of assets and other accounting rules and principles. In this context, we consider what lonașcu and Feleagă (1997) called a "simplifying recipe of true and fair view", this one resulting from the correct and consistent application of generally accepted accounting principles.

In this paper, we will consider compliance with the generally accepted accounting principles as a recipe of the true and fair view, further aiming to illustrate how each principle contributes to the achievement of this objective.

\section{True and fair view in financial reporting and generally accepted accounting principles}

The information produced and presented through financial statements is considered by Stolowy et al. (2013, p. 122) a social good that aims at the well-being of various categories of users who use it in the decisionmaking process. It therefore becomes necessary to establish and follow a series of rules. These rules are the accounting principles, found in the literature under titles such as conventions or accounting rules (Horomnea et al., 2016, p. 118). They form a coherent set of rules and behavioural guidelines, inductively described and with a high degree of generality that are used as a reference system for evaluating, classifying and presenting financial information (Horomnea, 2013, p. 252; Ionașcu, 2003, p. 68; Stolowy et al., 2013, p. 122).

Each country has such a set of principles (Generally Accepted Accounting Principles - GAAP), several of which are better known and leave their mark on accounting regulations in various countries. Examples of this are US GAAP, heavily influenced by US financial market regulators, and IAS/IFRS, which reflect the views of a large international user community (Stolowy et al., 2013, p. 122).

Starting from the analysis performed by Stolowy et al. (2013, p.122), figure below presents the Romanian accounting principles and postulates, which are very similar to those of the two sets of rules (American and IAS/IFRS), classified into four categories indicating four critical requirements imposed by users of financial information: objectivity, as users are interested in an impartial attitude, free from prejudice, conflicts of interest or external influence of the accountant in assessing and estimating (where appropriate) the value of the reporting entity's assets and liabilities; quality, because users are interested in detailed reports (without exaggerating because there is a risk of hiding essential information) that present in a faithful, neutral and relevant way the situation of the company at a given time; prudence, because, contrary to opinions about the potential conflict between true and fair view and conservatism principle, a cautious attitude (without excesses meant to manipulate the results) from the accountants is preferable to an overly optimistic one that can ultimately lead to the decapitalization of society; and timeliness, because users need the information to be made available to them as soon as possible, at regular intervals. 


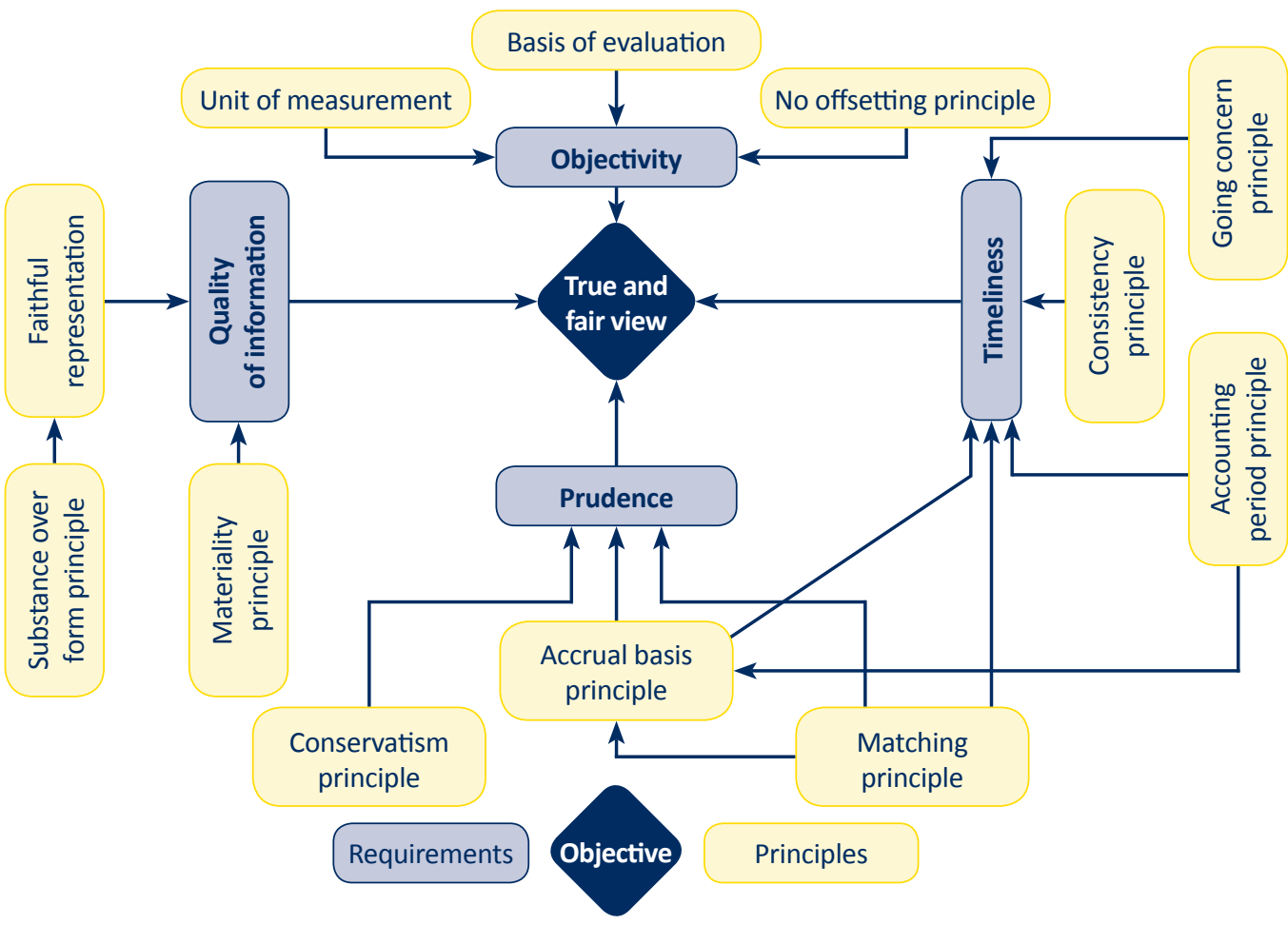

Generally accepted accounting principles and true and fair view

Source: Own processing after Stolowy et al., 2013.

As shown by the figure above, obtaining a true and fair view implies, on the one hand, compliance with the going concern principle, consistency, accounting period, accrual basis, conservatism, matching, materiality, substance over form and no offsetting principles which are found in an explicit form in Romanian accounting. Alternatively, obtaining it also implies compliance with the unit of measurement, basis of evaluation and business entity concept principles which are not described separately, being considered implicit (Matiș, 2017).

Table above presents and describes the two types of principles, with how each one contributes to obtaining the true and fair view.

The contribution of accounting principles to obtaining a true and fair view

\begin{tabular}{|c|c|}
\hline $\begin{array}{l}\text { Name and characteristics } \\
\text { of the principle }\end{array}$ & $\begin{array}{l}\text { How it contributes to obtaining } \\
\text { the true and fair view }\end{array}$ \\
\hline \multicolumn{2}{|c|}{ Objectivity } \\
\hline $\begin{array}{l}\checkmark \text { Unit of measurement principle } \\
\text { According to the Conceptual Framework (IASB, } \\
2010 \text {, para 4.54) this principle, considered implicit } \\
\text { and not presented separately in the Romanian } \\
\text { legislation, can be observed in the evaluation } \\
\text { process and ensures the determination of the values } \\
\text { at which the elements included in the financial } \\
\text { statements will be recognised in the balance sheet } \\
\text { and profit and loss. }\end{array}$ & $\begin{array}{l}\text { It ensures the homogenization and aggregation } \\
\text { of heterogeneous elements, using as common } \\
\text { denominator the national currency or another } \\
\text { currency of international circulation, which allows } \\
\text { all users to understand that each value means } \\
\text { approximately the same thing. As long as the values } \\
\text { from different reporting periods are aggregated, } \\
\text { users are presented with a complete picture of } \\
\text { the history of events that shaped the company's } \\
\text { financial position and allow them to estimate its } \\
\text { future evolution. }\end{array}$ \\
\hline
\end{tabular}




\begin{tabular}{|l|l|}
\hline \multicolumn{1}{|c|}{$\begin{array}{c}\text { Name and characteristics } \\
\text { of the principle }\end{array}$} & \multicolumn{1}{|c|}{$\begin{array}{c}\text { How it contributes to obtaining } \\
\text { the true and fair view }\end{array}$} \\
\hline \multicolumn{2}{|c|}{ Objectivity } \\
\hline $\begin{array}{l}\text { Financial accounting records only transactions } \\
\text { expressed in financial units (Romanian Leu, Euro, } \\
\text { US Dollar etc.), thus ensuring an expression } \\
\text { in monetary terms of their economic impact. }\end{array}$ & \\
\hline
\end{tabular}

\section{Example}

What if an IT company hired one of the brightest minds in the field? Or if a company in the pharmaceutical industry would lose the most valuable and productive member of the research and development team?

Then could this information be characterized as relevant, with a significant impact on future business results?

Compliance with this principle allows only the transactions expressed in monetary units to be recognised in the financial statements. The presented examples cannot be considered transactions as they do not have a value that can be established in a reliable manner. Even if such information is important in terms of business promotion and competition, given that its monetary quantification cannot be made on a reliable and demonstrable basis, its recognition is not capable of providing an uniform interpretation, in accordance with the true and fair view objective.

$\checkmark$ The principle of valuation at acquisition or production cost (historical cost principle) This means that, in the absence of revaluation, the items presented in the financial statements are recognised and carried in the balance sheet and income statement at acquisition or production cost. The valuation basis can be determined using several cost categories, as presented by the Conceptual Framework (IASB, 2018, paras 6.1-6.4), namely: historical cost, fair value, current cost, net realizable value and present value, the most used being the historical cost, usually combined with other valuation bases.
The recognition of assets and liabilities and the fact that they are carried in the balance sheet and income statement at the same value (under the historical cost assumption), regardless of price fluctuations, has as a consequence, in conditions of inflation or hyperinflation, the presentation of values that do not correspond to economic reality. However, in periods of economic stability, the objective nature and the possibility of confirmation with the documents underlying the records make historical cost a necessary factor in obtaining a true and fair view. We note in this respect that the overvaluation of assets, all the more than their underestimation, misleadingly represents the real situation, a situation that is of real interest to shareholders, these representing, in other words, the potential future cash flows. Stolowy et al. $(2013$, p. 124$)$ argue in this regard that accountants will move away from the possibility of overestimation and prefer the option of underestimation that users of accounting information can correct based on their knowledge of the market.

\section{Example}

How do we report a land acquired by company $Q$ in 1992 to the 250,000 lei value that the company still owns, 28 years later, its fair value far exceeding the input value?

According to the historical cost principle, in the absence of revaluation, the land will remain recorded at 250,000 lei until the sale or cessation of the entity's activity (as the land has unlimited useful life it may exceed the life of the enterprise), this value being based on indisputable evidence attesting the objective nature of the transaction. 


\begin{tabular}{|c|c|}
\hline $\begin{array}{l}\text { Name and characteristics } \\
\text { of the principle }\end{array}$ & $\begin{array}{l}\text { How it contributes to obtaining } \\
\text { the true and fair view }\end{array}$ \\
\hline \multicolumn{2}{|c|}{ Objectivity } \\
\hline \multicolumn{2}{|c|}{$\begin{array}{l}\text { The possibility to confirm the validity of the input value and the fact that the overestimation of the value } \\
\text { is avoided make the historical cost an instrument of the true and fair view. Under these conditions, unlike } \\
\text { the case of overestimating the value of the land, with minimal information obtained from the market } \\
\text { users could make their own estimates of the fair value of the asset. }\end{array}$} \\
\hline $\begin{array}{l}\checkmark \text { No offsetting principle } \\
\text { Generally, assets and liabilities and, similarly, } \\
\text { income and expenses must be reported separately } \\
\text { in the balance sheet and income statement. IAS } 1 \\
\text { Presentation of Financial Statements considers that } \\
\text { offsetting should not be allowed as it would reduce } \\
\text { the users' ability to understand transactions and } \\
\text { other events. However, the general rule does not } \\
\text { apply if another international standard allows } \\
\text { or requires compensation in certain cases. }\end{array}$ & $\begin{array}{l}\text { Two transactions can have the same effect of } \\
\text { absolute value with opposite algebraic signs. } \\
\text { The net balance of these two transactions would be } \\
\text { arithmetically zero, but such a presentation would } \\
\text { not reflect the economic "reality". Compliance with } \\
\text { the no offsetting principle does not allow hiding } \\
\text { part of a company's wealth or, in less fortunate } \\
\text { cases, masking the risks faced by the firm in each } \\
\text { transaction. }\end{array}$ \\
\hline
\end{tabular}

\section{Example}

How will company $Q$ account a receivable of 10,000 lei and a liability of 7,000 lei to the same company? According to the no offsetting principle, in order to ensure the presentation of complete and conclusive information, both the receivable and the liability will be presented separately in the balance sheet, even if they refer to the same company. In case of the existence of a compensation order (see Government Decision No. 773/2019), after accounting the receivable and the income, respectively the corresponding liability and expense, the compensation takes place, in the accounting of company $Q$ resulting in the difference of 3,000 lei, up to the competition of the 10,000 lei receivable, which will be settled by bank or cash.

\section{The quality of information}

\section{$\checkmark$ Faithful representation}

This cannot be assimilated to an accounting principle/postulate/convention, since this is, along relevance, a fundamental characteristic of the quality financial information.

Financial information must not only represent the relevant phenomena, but must also exactly represent the phenomena it represents, thus referring to the concept of "faithful representation". Compliance with this requirement contributes to the true and fair view by ensuring that the financial statements provide a neutral, free from errors and/or omission presentation.

\section{$\checkmark$ The substance over form principle}

Provides for the obligation to record economic transactions in accordance with their economic form, to the detriment of legal form. This is a concept incorporated into accounting standards in recent decades and whose application leads to the provision of reliable information in the financial statements issued by companies.

\section{Example}

Company $Q$ has an ongoing financial leasing contract concluded for the purchase of a machine and a contract for the provision of storage and processing services concluded with company $Z$ which sent for storage and processing stocks of raw materials worth of 25,000 lei. 
How it contributes to obtaining the true and fair view

The two situations are analysed resulting in the following judgements:

- According to the terms of the lease, the risks and benefits of the machine have been transferred to company $Q$ even if, from a legal point of view, the machine is not its property, but belongs to the leasing company. From an economic point of view, however, the machine will be recognised in the financial statements of the company $Q$.

- According to the clauses of the contract for the provision of storage and processing services, the risks and benefits related to these stocks belong to the owner, namely company Z. Thus, from a legal point of view, the stocks received for storage and processing are not owned by company $Q$, and from economically, their value will not be recorded in the financial statements of the company, but only off-balance sheet.

- The inclusion of the machine in the company's assets and the value of the inventories received for storage and processing using off-balance sheet accounts does not allow the information to be distorted, thus faithfully reflecting the economic impact of the operations.

$\checkmark$ The materiality principle

The information is considered significant if its omission or misrepresentation could influence users in the decision-making process. In other words, the following two requirements must be considered: any item of significant value must be presented separately in the financial statements and items of insignificant value of the same or similar nature must be added together.

Determining the materiality level is an essential aspect, both in accounting and auditing. However, both international and Romanian legislation do not provide for a specific level, leaving it to the discretion of accountants and auditors to determine whether an information or a situation presented can significantly influence users' decisions (CECCAR, 2019).
Establishing an acceptable level of materiality contributes to an overview of the economic reality of an enterprise because, on the one hand, it ensures that the information presented is not too condensed or too aggregated, which makes it difficult to use it, and, on the other hand, it prevents the agglomeration with insignificant and unnecessary details of the financial statements, which makes it difficult to interpret them and at the same time can raise questions about the represented economic reality.

\section{Example}

How do we report an extraordinary loss of approximately 15,000 Euros regarding a company warehouse destroyed by $60 \%$ in the aftermath of floods?

Considering the requirements of the materiality principle, it can be concluded that for a large company with a turnover of about 10,000,000 Euros, this loss can be considered insignificant, users not being so concerned about something that represents only $0.15 \%$ of the turnover. For a small company, on the other hand, which has a turnover of about 80,000 Euros, this loss, which is approximately 19\% of the turnover, is a substantial one that would worry investors and creditors alike. If in the first case the loss can be presented together with other elements of a similar nature, their value being cumulated, in the case of a small company, this loss is the subject of a separate and detailed record highlighting the impact of this situation on the financial statements. In both cases, we note that establishing an optimal level of materiality ensures a comprehensive presentation of the company's activity facilitating their analysis and interpretation by interested users. 


\begin{tabular}{|l|l|}
\hline \multicolumn{1}{|c|}{$\begin{array}{c}\text { Name and characteristics } \\
\text { of the principle }\end{array}$} & \multicolumn{1}{c|}{$\begin{array}{c}\text { How it contributes to obtaining } \\
\text { the true and fair view }\end{array}$} \\
\hline $\begin{array}{l}\text { Prudence } \\
\text { Implies that in preparing financial statements } \\
\text { the recognition and measurement should be made } \\
\text { on a prudent basis, including only the profit made } \\
\text { up to the balance sheet date, all liabilities (even } \\
\text { if they become apparent between the balance } \\
\text { sheet date and the date of preparation) and all } \\
\text { impairments, regardless of the nature of the result. } \\
\text { Regarding the assets, their overvaluation is not } \\
\text { allowed. }\end{array}$ & $\begin{array}{l}\text { The relationship between conservatism and the true } \\
\text { and fair view is controversial, considering that, at first } \\
\text { sight, the pessimism induced by conservatism and the } \\
\text { neutral nature of the true and fair view are at odds. } \\
\text { Leaving the pessimism associated with this principle } \\
\text { in the background, compliance with conservatism } \\
\text { also leads to the recognition in the financial } \\
\text { statements of the potential risks faced by a company, } \\
\text { through provisions and depreciation/impairment } \\
\text { adjustments. Under these conditions, the role } \\
\text { of conservatism becomes confusing, sometimes } \\
\text { oscillating between its exclusion or acceptance } \\
\text { with reservations. It should be emphasised in this } \\
\text { case that the potential risks should be approached } \\
\text { with moderate caution, without making excessive } \\
\text { or unjustified provisions/adjustments. } \\
\text { In accordance with the Romanian accounting } \\
\text { regulations that support compliance with } \\
\text { conservatism to obtain a true and fair view, we } \\
\text { can conclude that compliance with this principle, } \\
\text { according to the rules and in good faith, leads to a } \\
\text { realistic and balanced estimate of the risks to which } \\
\text { a business is exposed, which leads to a relevant, } \\
\text { overall (complete), free from errors, omissions and } \\
\text { consistent with neutrality presentation, foundation } \\
\text { of a quality financial reporting, able to faithfully } \\
\text { represent the economic reality. } \\
\text { Applying conservatism in a "creative" manner that } \\
\text { involves taking advantage of legislative gaps, } \\
\text { existing accounting options, etc., leads to poor } \\
\text { quality reports that cannot accurately present } \\
\text { economic reality. }\end{array}$ \\
\hline
\end{tabular}

\section{Example}

During the financial year 2019, company $Q$ is sued by a business partner (company Z), the lawyers considering that it is possible that the company will lose this process and that it will have to pay compensations amounting to 1,875,000 lei. This results in a risk to which the company is exposed, which has the potential to generate a debt capable of destabilizing the economic situation. As long as the estimates indicate that the likelihood of the lawsuit being lost is greater than the likelihood that it will not, company $Q$ is entitled to recognize a provision for litigation at the level of damages and estimated costs.

Even if at the level of 2019 the value of 1,875,000 lei represents only a potential debt for which there is no certainty that it will be settled in the future, its impact on the result can be estimated reliably, according to the claims made, thus the presentation of this information does nothing more but to complete the overall picture, contributing to the true and fair view objective. 


\begin{tabular}{|l|c|}
\hline $\begin{array}{c}\text { Name and characteristics } \\
\text { of the principle }\end{array}$ & $\begin{array}{c}\text { How it contributes to obtaining } \\
\text { the true and fair view }\end{array}$ \\
\hline \multicolumn{2}{|c|}{ Prudence } \\
\hline \multicolumn{2}{|c|}{} \\
\hline
\end{tabular}

In turn, in the spirit of the conservatism principle and considering it probable to win the process (with some degree of uncertainty involved), company $Z$ does not recognize the potential gain, thus avoiding creating a false image of the company's assets in front of current and potential investors. The presentation of a worse situation than in reality, as opposed to the opposite case of presenting a better situation, but marked by the possibility of failure, presents from this point of view a much higher degree of trust in front of users who have in front the complete picture of the economic and the surrounding risks.

A very important aspect that emerges from the examples is the most credible and accurate risk assessment when establishing the provision, respecting both the requirements of conservatism and those of the true and fair objective.

\section{$\checkmark$ The accrual accounting principle}

Involves the recognition of transactions and events on the basis of supporting documents proving their existence when they occur and not at the time of their settlement.

\section{$\checkmark$ The matching principle}

Derived from the accrual accounting principle, involves the recognition and recording of expenses at the same time as the corresponding income, i.e. expenses and income that are related to a certain accounting period should be reported in the same period. Difficulties arise when certain expenses and income are incurred for several years, in which case the prepaid expenses and revenues are used, with the help of which the receivables and payables related to the following financial year are recorded in the current year. (CECCAR, 2018)

In Pct. 53 Alin. (2) of the Order of the Minister of Public Finance No. 1802/2014 for the approval of the Accounting regulations regarding the individual annual financial statements and consolidated annual financial statements, as subsequently amended and supplemented, effective since January 1st, 2015, the matching principle is no longer expressly recognised, specifying the following: "Revenues and expenses related to the financial year must be taken into account, regardless of the date of collection of income or date of payment of expenses. Thus, the accounts for which the invoice has not yet been drawn up will be highlighted in income accounts and receivables (...), respectively, in the expense or goods accounts, the debts for which the invoice has not yet been received (...).

\section{Unlike cash accounting, which is based on} an ultra-prudent premise that does not serve the interests of users of accounting information that are more interested in the future than in the past (Matiș et al., 2005), the practice of accrual accounting and the use of prepaid expenses and revenues leads to the presentation of information not only about past transactions, which involved payments and receipts, but also about future payment obligations and future rights, thus providing a complete picture of the activity carried out by the enterprise. 


\begin{tabular}{|l|l|}
\hline \multicolumn{1}{|c|}{$\begin{array}{c}\text { Name and characteristics } \\
\text { of the principle }\end{array}$} & \multicolumn{1}{|c|}{$\begin{array}{c}\text { How it contributes to obtaining } \\
\text { the true and fair view }\end{array}$} \\
\hline \multicolumn{2}{|c|}{ Prudence } \\
\hline $\begin{array}{l}\text { In all cases, the registration in these accounts } \\
\text { is made on the basis of documents certifying } \\
\text { the delivery of goods, respectively, the provision } \\
\text { of services (for example, notices accompanying } \\
\text { goods, work situations, etc.)". In other words, it can } \\
\text { be seen that the accrual accounting principle has } \\
\text { replaced the matching principle. }\end{array}$ \\
\hline
\end{tabular}

\section{Example}

In December 2020, the company performed renovation works for a business partner in the amount of 18,000 lei, to be settled in March 2021.

Respecting the requirements of accrual accounting, company $Q$ recognizes the income of 18,000 lei (and implicitly the profit) related to this benefit in the financial year 2020, in accordance with the date of execution of the works, thus anticipating the future economic benefits that this will generate, and not in 2021 at the time of the settlement. The recognition of revenues at the time of invoicing and not the actual settlement serves the interests of current and potential investors providing them with an overview of the company's performance. The recognition of income strictly at the time of the settlement can be considered an exaggeration of conservatism, especially given that the economic entity do not show signs of financial instability, thus contributing to the formation of an image without prospects, simplistic, which does not completely capture the complexity of the company's activity.

\section{Timeliness}

\section{$\checkmark$ The accounting period principle}

Assumes that the opening balance sheet for each financial year corresponds to the closing balance sheet for the previous financial year. This means that changes in accounting policies, procedures and methods during a financial year cannot be applied retroactively. The errors of the previous period are corrected using retained earnings and not by changing the opening balance sheet.

Ensuring a correct and complete information of the interested users regarding the company's activity (Matiș, 2017) in a determined time period. Given that the error corrections cannot be attributed to transactions or events of the period, their reflection on account of the retained earnings and not on account of the current result of the year in which they were identified ensures the reflection of the economic reality of the current period.

\section{Example}

Company $Q$ finds in June 2021 that an invoice amounting to 6,500 lei from November 2020 has not been registered in the accounts.

Considering the fact that the financial statements related to the previous financial year have been prepared and submitted, the application of this principle implies the registration of the invoice on account of the retained earnings, in order to ensure a correct information on the financial year 2021 events.

\section{$\checkmark$ The consistency principle}

Implies that an entity must apply valuation methods and policies consistently from one year to the next to ensure the comparability of financial information over time. A change in an accounting method or policy occurs either if required by regulation or if the current methods do not lead to relevant, credible and useful results in the decision-making process.

\section{Given the fact that different accounting methods} and policies lead to different results, compliance with this principle leads to increased comparability and, consequently, the usefulness of financial statements, giving users the opportunity to make comparisons between figures presented at the end of a financial year with those presented at the end of the previous year. 


\begin{tabular}{|l|c|}
\hline $\begin{array}{c}\text { Name and characteristics } \\
\text { of the principle }\end{array}$ & $\begin{array}{c}\text { How it contributes to obtaining } \\
\text { the true and fair view }\end{array}$ \\
\hline \multicolumn{2}{|c|}{ Timeliness } \\
\hline
\end{tabular}

If they need to be changed, the reasons and their

effects on the financial reporting should be set out

in the explanatory notes.

\section{Example}

Consider the case of a car manufacturer that uses the LIFO method for stock consumption and has been advised by financial advisors to change the method to FIFO.

According to the consistency principle, this is allowed as long as it can be proved that the LIFO method no longer lead to the correct and reliable account of the stock situation. If the company, which succeeded in justifying the change in the valuation method in a first phase, decides next year to return to the LIFO method (e.g. for tax reasons), the last change would be considered a violation of the principle that the company could no longer justify. It is therefore noted that changing methods in the spirit of compliance with this principle is not prohibited, especially if it aims to reflect results with increased relevance and credibility, but it must be justified and also explained in the annexes (presentation of the context of change and impact on the financial position situation and results).

\section{$\checkmark$ The going concern principle}

Implies that the company will continue its business as usual, without significantly reducing its activity or entering liquidation. Depending on the two situations in which the entity can be found, continuity or discontinuity, there are two options: the items included in the financial statements are valued at market value, utility value (in case of continuity) and liquidation value (in case of discontinuity). When the directors of an entity have become aware of certain elements of uncertainty related to certain events that may lead to its inability to continue its activity, those elements must be presented in the explanatory notes. If the annual financial statements are not prepared on a going concern basis, this information must be presented, with the reasons for the decision that the company may no longer operate.
The going concern principle implies, in turn, compliance with conservatism, consistency and matching principles. The ability to accumulate income and expenses and therefore to reflect them in the appropriate time periods assumes that an economic entity has a life expectancy that exceeds the accounting reporting period. As long as this principle is respected, the comparability and credibility of the financial reporting are ensured.

\section{Example}

At the end of the financial year 2020, company Q operating in the textile and clothing industry evaluates work in progress stocks amounting to 2,050,000 lei (production cost). As a result of the crisis caused by the coronavirus, which led to the limitation or even cessation of activity for some of the company's major clients and the impossibility of paying short and long-term bank loans, company Q prepares financial statements under the discontinuity premise.

In these conditions for the work in progress stocks a liquidation value will be established which can be much lower than the production cost and possible liabilities resulting from possible penalties, dismissals, etc.) must be considered in the balance sheet. It can thus be seen that ignoring certain events that can lead to the inability of a company to continue its activity leads to the reflection of values that do not represent the economic reality. 
Ionașcu (2003) considers that it cannot be neglected that there are almost conflicting states between some described principles and the true and fair view objective. As can be seen from the description of each contribution, potential conflicts can be noted regarding the relationship between the conservatism principle and the true and fair view objective (on the one hand, we support the idea that conservatism leads to the evaluation in a credible manner of the risks manifested in the activity of a company, which leads to the completion of the overall picture of the carried out transactions, and on the other hand, we argue that this leads to a non-neutral approach, which contradicts the stated purpose of financial reporting) and the influence of the valuation using the historical cost on the reflection of the economic reality (the keeping of the goods in the accounting at the input value, without taking into account the price fluctuations have as a consequence, in conditions of inflation or hyperinflation, the presentation of values that do not correspond to the economic reality, which contradicts the true and fair view objective).

\section{P Conclusions}

Once accepted in the accounting regulations of the continental countries, the true and fair view concept was assimilated to the financial reporting objective and its achievement was seen mainly by complying with the generally accepted accounting principles and, simultaneously, with the quality of financial accounting information requirements.

In the absence of a clear and universally accepted definition by all accountants, the interpretation of the true and fair view oscillated between two orientations, a legal one according to which the financial statements represent the true and fair view when prepared in accordance with current legal regulations and an economic one that assumes that the financial statements represent the economic reality of the company, although for this it no longer complies with certain legal provisions.

It can be concluded that, considering the role of each principle, the true and fair view recipe involves contributions such as: aggregating values from different reporting periods in order to outline a complete picture of the history of events that shaped the company's financial position, separate recognition without offsetting for assets and liabilities in order to avoid hiding part of a company's wealth or, in less fortunate cases, masking the risks faced by the company in each transaction, accurate, free of errors/omissions and neutral representation of transactions, establishing an acceptable materiality level that does not allow over-condensation of information or overcrowding with insignificant details, reflection of the economic background of the transaction to the detriment of the legal one, realistic and balanced estimation of risks and losses, presentation of past rights and obligations without being limited of term their effective settlement.

Also regarding the interpretation of the concept from a legal perspective, analysing the definition and contribution of each accounting principle to obtain the true and fair view, almost conflicting states can be observed between some accounting principles and the financial reporting objective, among which are worth mentioning the controversies about the effect of valuing items in financial statements based on historical cost to the detriment of current values and those about the effect of pessimism associated with the conservatism principle, the development of the two potential conflicts representing distinct research directions for future research.

\section{References}

1. Beke, J. (2013), International Accounting Harmonization. Adopting Universal Information Methods for a Global Financial System, Palgrave Macmillan, New York.

2. Cañibano, L. (2006), El concepto de imagen fiel y su aplicación en España, Partida Doble, No. 178, pp. 10-17.

3. Cañibano, L., Herranz, F. (2013), Principios versus reglas en las normas contables, Consejeros, pp. 56-62. 
4. Ciocan, C.C., Georgescu, I. (2018), An Analysis of the International Research on the Relationship Between Prudence and True and Fair View in Financial Reporting, Journal of Eastern Europe Research in Business and Economics, pp. 1-16.

5. Colasse, B. (2009), Fundamentele contabilității, traducere N. Tabără, Editura TipoMoldova, laşi.

6. Collet, S.A. (1990), Imagen fiel y principios contables, Revista Española de Financiación y Contabilidad, Vol. 20, No. 63, pp. 351-361, http://dialnet.unirioja.es/descarga/articulo/44001.pdf.

7. Evans, L. (2003), The True and Fair View and the "Fair Presentation" Override of IAS 1, Accounting and Business Research, Vol. 33, No. 4, pp. 311-325.

8. Gómez Ciria, A. (1997), La imagen fiel y los principios contables públicos, Auditoria Publica, No. 12, pp. 45-52.

9. Horomnea, E. (2013), Dimensiuni științifice, sociale și spirituale în contabilitate. Geneză, doctrină, normalizare, decizii, ediția a V-a, Editura TipoMoldova, laşi.

10. Horomnea, E., Budugan, D., Georgescu, I., Istrate, C., Păvăloaia, L., Rusu, A. (2016), Introducere în contabilitate. Concepte și aplicații, Editura TipoMoldova, laşi.

11. Ionașcu, I. (2003), Dinamica doctrinelor contabilității contemporane: studii privind paradigmele şi practicile contabilității, Editura Economică, București.

12. Kumor, I., Mackowiak, E. (2018), Materiality in Accounting and Auditing, in Economic and Social Development (Book of Proceedings), 32nd International Scientific Conference on Economic and Social Development, pp. 218-225.

13. Matiș, D. (2017), Bazele contabilității. Metoda contabilității, https://econ.ubbcluj.ro/ victor.muller/ Download/BC/Curs 2017/BC - Partea III 2017.pdf.

14. Matiş, D., Mustață, R., Achim, S., losivan, R., Groşanu, A., Berinde, S. (2005), Bazele contabilității pentru viitori economiști, Editura Dacia, Cluj-Napoca.

15. Melville, A. (2017), International Financial Reporting. A Practical Guide, 4th Edition, Pearson.

16. Nobes, C., Parker, R. (2016), Comparative International Accounting, 13th Edition, Pearson.

17. Stolowy, H., Lebas, M.J., Ding, Y. (2013), Financial Accounting and Reporting. A Global Perspective, 4th Edition, Cengage Learning EMEA, London.

18. CECCAR (2018), Principiile generale de raportare financiară, CECCAR Business Magazine, No. 36, http:// www.ceccarbusinessmagazine.ro/principiile-generale-de-raportare-financiara-a3886/.

19. CECCAR (2019), Conceptul de prag de semnificație aplicat în contabilitate și audit, CECCAR Business Magazine, No. 23, http://www.ceccarbusinessmagazine.ro/conceptul-de-prag-de-semnificatie-aplicat-in-contabilitatesi-audit-a5049/.

20. IASB (2010), Conceptual Framework for Financial Reporting, https://ifrs.seo.ir/ Admin/FilelmageBrowser/ GetFile?path=IFRSs\%2Fconceptualframework. pdf.

21. IASB (2018), Conceptual Framework for Financial Reporting, https://www.iasplus.com/en/standards/other/ framework.

22. Accounting Law No. 82/1991, republished in Official Gazette No. 454/18.06.2008, as subsequently amended and supplemented.

23. Order of the Minister of Public Finance No. 1802/2014 for the approval of the Accounting regulations regarding the individual annual financial statements and consolidated annual financial statements, Official Gazette No. 963/30.12.2014, as subsequently amended and supplemented.

24. Regulation No. 704/1993 on the application of Accounting Law No. 82/1991, Official Gazette No. 303 bis/ 22.12.1993, repealed. 